\title{
The effect of amifostine on bacterial translocation after radiation induced acute enteritis ${ }^{1}$
}

\author{
Sukru Tas', Faruk Ozkul', Muhammet Kasim Arik ${ }^{\text {III }}$, Asli Kiraz ${ }^{\text {IV }}$, Ahmet Vural ${ }^{\mathrm{V}}$
}

DOI: http://dx.doi.org/10.1590/S0102-865020160030000002

\author{
IAssistant Professor, Department of General Surgery, Çanakkale Onsekiz Mart University, Faculty of Medicine, Çanakkale, Turkey. Conception and \\ design of the study, manuscript preparation. \\ IIAssistant Professor, Department of General Surgery, Çanakkale Onsekiz Mart University, Faculty of Medicine, Çanakkale, Turkey. Acquisition of \\ data, technical procedures. \\ IIIAssistant Professor, Department of General Surgery, Çanakkale Onsekiz Mart University, Faculty of Medicine, Çanakkale, Turkey. Acquisition of \\ data, statistical analysis. \\ ${ }^{\mathrm{I}} \mathrm{MD}$, Department of Medical Microbiology, Çanakkale Onsekiz Mart University, Faculty of Medicine, Çanakkale, Turkey. Analysis and interpretation \\ of data, critical revision. \\ vAssistant Professor, Department of Medical Microbiology, Çanakkale Onsekiz Mart University, Faculty of Medicine, Çanakkale, Turkey. Manuscript \\ writing, final approval.
}

\section{ABSTRACT}

PURPOSE: To investigate the effects of amifostine on bacterial translocation and overgrowth in colonic flora after acute radiation enteritis in a rat model.

METHODS: Thirty-two female Wistar albino rats were divided into four groups: Group-1 $(\mathrm{n}=8)$ : only normal saline was administered intraperitoneally. Group-2 $(\mathrm{n}=8)$ : first serum saline was administered intraperitoneally and 30 minutes later 20 Gy radiation was applied to abdominopelvic region. Group-3 ( $\mathrm{n}=8)$ : only amifostine $200 \mathrm{ml} / \mathrm{kg}$ was administered intraperitoneally and radiation was not applied. Group-4 ( $\mathrm{n}=8$ ): first amifostine $200 \mathrm{ml} / \mathrm{kg}$ was administered intraperitoneally and 30 minutes later 20 Gy radiation was applied to abdominopelvic region. On the 5 th day after radiation, samples of mesenteric lymph tissues and cecal contents were taken by laparotomy for microbiological culture.

RESULTS: Intraperitoneal amifostine administration significantly decreased the bacterial overgrowth related to radiation in colon but did not significantly decrease the bacterial translocation.

CONCLUSION: Although not providing a full protection on the damaged mucosal barrier, amifostine significantly decreased the bacterial overgrowth in the cecal content after high dose radiation. There is a need to find out appropriate amifostine dose under different radiation applications avoiding bacterial translocation in gastrointestinal system.

Key words: Amifostine. Bacterial Translocation. Enteritis. Radiation. Rats. 


\section{Introduction}

Radiation was first described by Willhelm Conrad Roentgen as a new type of beam in $1895^{1}$. After development of science radiation has been successfully used for cancer treatment in the world. Nevertheless it is well known that radiotherapy can cause adverse toxic effects on the surrounding tissues.

Gastrointestinal tract is the second sensitive organ to radiation after bone marrow ${ }^{2}$. For this reason, radiotherapy (RT) application to abdominal region can cause a clinical tableu called acute radiation enteritis with inflammation, edema, epithelial degeneration, ulceration, decrease in mitotic activity and crypt abscess in gastrointestinal tractus ${ }^{3,4}$. In clinical practice acute radiation enteritis can cause several intestinal symptoms such as bleeding, anorexia, nausea, vomiting and diarrhea, called gastrointestinal radiation syndrome ${ }^{5,6}$.

Bacterial translocation is defined as the passage of viable endogenous bacteria and endotoxins from the gastrointestinal (GI) tract to extraintestinal sites, such as the mesenteric lymph node complex, liver, spleen, kidney and bloodstream ${ }^{7,8}$. Recent literature showed that, a significantly increase in the bacterial overgrowth and translocation by destroying the intestinal mucosal barrier and affecting intestinal peristaltic movement is seen in the abdominal region affected by radiation ${ }^{4,8}$. This complication can be seen approximately in $10-15 \%$ of the patients after abdominal radiation theraphy and is the most important limiting factor for the radiotherapy dose in the abdominopelvic region ${ }^{9}$.

In cancer treatment, there is an increasing need for developing new radioprotective agents to eliminate or minimize the radioactive damage by ionized radiation. Amifostine is an organic triphosphate with cytoprotective and antioxidant effects. The protective activity of amifostine on tissues against chronic effects of radiation is controversial due to its short half-life period, that is approximately eight minutes ${ }^{10}$. However, the radioprotective effect of amifostine against acute toxic effects of radiation was prooved on both breast, bladder, neck, head, ovary, and rectal cancers in many studies ${ }^{11}$.

The protective effects of amifostine on different radiation types and doses in acute period were studied in recent literature, but there are no study evaluating effects of amifostine on bacterial overgrowth and translocation after acute radiation enteritis ${ }^{12-14}$. In our study, the effects of amifostine on both bacterial translocation and bacterial overgrowth in colonic flora after acute radiation enteritis were evaluated in a rat model.

\section{Methods}

This study was performed in DUSAM (Dicle University Health Sciences Research and Application Center) laboratory with the approval of Laboratory Animals Ethics Committee of Dicle University (approval $n^{\text {o: }}$ 2013/25) and Çanakkale Onsekiz Mart University (approval no: 2012/82).

A total of 32 female six months old Wistar-albino rats (180-220 grams) included in our study. They were obtained from Laboratory Animal Research Center of Dicle University. All the rats were followed in special metal cages, at room temperature and stable environmental conditions $\left(21 \pm 2^{\circ} \mathrm{C}\right.$ and 12 hour light/dark cycles) and were fed with normal water and standard food. No food and water restrictions were applied to animals. The rats were divided into four groups as summarized in Table 1.

Group-1: $(\mathrm{n}=8)$ Evaluated as control group and only sterile saline $(200 \mathrm{ml} / \mathrm{kg})$ was administered intraperitoneally.

Group-2: ( $\mathrm{n}=8) \quad$ Sterile saline $(200 \mathrm{ml} / \mathrm{kg})$ was administered intraperitoneally and a dose of 20 Gy radiation was applied to abdominopelvic region 30 minutes later.

Group-3: ( $\mathrm{n}=8)$ Only amifostine $(200 \mathrm{ml} / \mathrm{kg})$ was administered intraperitoneally.

Group-4: ( $\mathrm{n}=8)$ Amifostine $(200 \mathrm{ml} / \mathrm{kg}$ ) was administered intraperitoneally and a dose of 20 Gy radiation was applied to abdominopelvic region 30 minutes later.

TABLE 1 - Distribution of groups.

\begin{tabular}{cccc}
\hline Groups (n) & $\begin{array}{c}\text { Amifostine } \\
(\mathbf{2 0 0} \mathbf{~ m l} / \mathbf{k g})\end{array}$ & $\begin{array}{c}\text { Sterile } \\
\text { saline } \\
\mathbf{( 2 0 0 ~} \mathbf{~ m l} / \mathbf{k g})\end{array}$ & $\begin{array}{c}\text { Radiation } \\
\mathbf{( 2 0 ~ G y )}\end{array}$ \\
\hline Group-1 (n=8) & No & Yes & No \\
Group-2 (n=8) & No & Yes & Yes \\
Group-3 (n=8) & Yes & No & No \\
Group-4 $(\mathrm{n}=8)$ & Yes & No & Yes \\
\hline
\end{tabular}

Amifostine (Ethyol ${ }^{\circledR} 98500 \mathrm{mg} / 10 \mathrm{ml}$, Er-Kim, Turkey), sterile saline (Bioflex Bag, $100 \mathrm{ml}$, Biosel, İstanbul, Turkey), xylazine (Rompun ${ }^{\circledR}$ Bayer AG, Leverkusen, Germany) and ketamine (Ketasol 10\%, Richter Pharma AG, Wels, Austria) were obtained and used in this study.

Rats in supine position were fixed with flasters from extremities. A single dose of $20 \mathrm{~Gy}$ radiation was applied from 80 $\mathrm{cm}$ with ALCYON-II model cobalt-60 teletherapy unit (General 
Electric/GE Healthcare) under general anaesthesia with $10 \mathrm{mg} / \mathrm{kg}$ xylazine and $90 \mathrm{mg} / \mathrm{kg}$ intramuscular ketamine.

On the 5 th day after radiation, laparotomy was performed under anesthesia as described above. After antisepsis, laparotomy performed with midline incision. Stool samples were obtained from the cecal content for coproculture while mesentery lymph tissues were dissected carefully in a sterile manner. Mesentery lymph tissue samples were homogenized in $1000 \mathrm{ml}$ trypticase soy broth using disposable tissue grinders (Baxter, Chicago, IL) and $200 \mathrm{ml}$ was plated on Columbia agar. All culture plates were evaluated after 48 hours incubation at $37^{\circ} \mathrm{C}$. Plates were considered positive if any bacterial growth was noted. One gr of caecal samples were put into sterile tubes seperately. Rats were euthanased under general anesthesia. The collection of contents of caecum and cultivation was performed according to the method defined previously ${ }^{15}$. Samples were homogenized in stomacher by adding $9 \mathrm{ml}$ of sterile saline. Serial tenfold dilutions were prepared up to $10^{-9}$ from obtained main dilution. All prepared solutions were cultivated at the same time. Plate Count Agar (PCA) (Merck 1.05463, Germany), a general purpose media was used in determining the total mesophilic aerob bacterial (TMAB) count. All culture plates were evaluated after 48 hours incubation at $37^{\circ} \mathrm{C}$ and the results were recorded as CFU/g (colony forming unit/gram). Violet Red Bile Glucose Agar (VRBGA) (Oxoid CM 485, Hampshire, England) was used for counting enteric bacteria. After 24 hours of incubation at $37^{\circ} \mathrm{C}$, all plates were evaluated by double layer pouring technique for red-violet colored colonies with 1-2 mm diameter and results were recorded as CFU/g.

The data was statistically analyzed with SPSS 12.0 program. The differences between the groups were determined by Kruskal-Wallis test on TMAB and enteric bacterial counts from the inoculation of the cecal content. After performing benferroni correction the groups were compared with Mann-Whitney U test in pairs. $p<0.005 / 6$ (i.e. $p<0.008$ ) was considered to be significant. Number of rats in every group, with or without overgrowth in their mesentery lymph nodes were detected. Chi square test was performed to determine the difference between groups. Fisher's Exact test was used for verification and the difference of groups was admitted significant $\mathrm{p}<0.005$.

\section{Results}

Radiation induced diarrhea and abdominal distension was observed after 24 hours in all rats in both group- 2 and group- 4 affected by radiation. These symptoms did not seen in rats in both group-1 and group-3. Mean bacterial count per gram was determined in stool samples from cecal content showed the bacterial overgrowth. The total mesophilic aerob bacterial counts (TMAB), minimum, maximum and mean enteric bacterial counts are shown in Table 2.

The mean of TMAB isolated in stool samples taken from the caecum of rats were $30.7 \times 10^{6}$ in group- $1,248 \times 10^{6}$ in group-2, $47.6 \times 10^{6}$ in group-3 and $28.88 \times 10^{6}$ in group-4 (Table 2). The mean of enteric bacterial counts were $0.4 \times 10^{6}, 6.72 \times 10^{6}, 2.25 \times 10^{6}$ and $1.36 \times 10^{6}$ in the groups, respectively (Table 2 ). There was a statistically significant increase in TMAB and enteric bacterial count in stool samples of group-2 compared to group-1 (TMAB $p=0.003$, enteric bacteria $p<0.001)$. There was no statistically significant increase in TMAB count but a significant increase was seen in enteric bacterial counts between groups 1 and 3 (TMAB $p=0.01$, enteric bacteria $p<0.001$ ). A significant decrease detected both in TMAB counts and enteric bacterial counts after radiation in group -4 compared to group -2 (TMAB $p=0.007$, enteric bacteria $\mathrm{p}=0.005)$.

TABLE 2 - Mean bacterial counts in groups from cecal content.

\begin{tabular}{|c|c|c|c|c|}
\hline & $\begin{array}{c}\text { Group-1 }(\mathbf{n}=8) \\
\text { CFU/g } \\
\text { Mean } \\
\text { (min-max) }\end{array}$ & $\begin{array}{c}\text { Group-2 }(\mathbf{n}=8) \\
\text { CFU/g } \\
\text { Mean } \\
(\text { min-max })\end{array}$ & $\begin{array}{c}\text { Group-3 }(\mathbf{n}=8) \\
\text { CFU/g } \\
\text { Mean } \\
(\text { min-max })\end{array}$ & $\begin{array}{c}\text { Group-4 }(\mathrm{n}=8) \\
\text { CFU/g } \\
\text { Mean } \\
\text { (min-max) }\end{array}$ \\
\hline $\begin{array}{l}\text { The Total Mesophilic } \\
\text { Aerob Bacterial Count }\end{array}$ & $\begin{array}{c}30.7 \times 10^{6} a \\
\left(0.24 \times 10^{6}-220 \times 10^{6}\right)\end{array}$ & $\begin{array}{c}248.4 \times 10^{6 \mathrm{a}, \mathrm{d}} \\
\left(12 \times 10^{6}-700 \times 10^{6}\right)\end{array}$ & $\begin{array}{c}47.6 \times 10^{6} \\
\left(14 \times 10^{6}-95 \times 10^{6}\right)\end{array}$ & $\begin{array}{c}28.88 \times 10^{6 \mathrm{~d}} \\
\left(19 \times 10^{6}-680 \times 10^{6}\right)\end{array}$ \\
\hline $\begin{array}{c}\text { Enteric Bacterial Count } \\
\text { in Stool }\end{array}$ & $\begin{array}{c}0.4 \times 10^{6} \mathbf{b}, \mathbf{c} \\
\left(0.05 \times 10^{6}-0.25 \times 10^{6}\right)\end{array}$ & $\begin{array}{c}6.72 \times 10^{6 \mathbf{b}, \mathbf{e}} \\
\left(0.23 \times 10^{6}-17 \times 10^{6}\right)\end{array}$ & $\begin{array}{c}2.25 \times 10^{6} \mathbf{c} \\
\left(0.22 \times 10^{6}-4.6 \times 10^{6}\right)\end{array}$ & $\begin{array}{c}1.36 \times 10^{6} \mathrm{e} \\
\left(0.31 \times 10^{6}-1.7 \times 10^{6}\right)\end{array}$ \\
\hline
\end{tabular}

$\mathbf{a}=\mathrm{p}: 0.003$ as statistically significant; $\mathbf{b}=\mathrm{p}<0.001$ as statistically significant; $\mathbf{c}=\mathrm{p}: 0.01$ as statistically significant; $\mathbf{d}=\mathrm{p}: 0.007$ as statistically significant; $\mathbf{e}=\mathrm{p}: 0.005$ as statistically significant.

When we examined the culture results of mesenteric lymph tissue samples of group-1, only one positive result was detected from a rat. All culture results were found positive in group-2. In the line of this data we can say that radiation significantly increased the bacterial translocation in rats $(\mathrm{p}=0.001)$. In group- 3 , two culture results were positive and in group- 4 , four 
culture results were positive. There was no statistically significant difference between groups 1 and 3 . In comparison of group-2 and group-4, it was determined that amifostine decreased the bacterial translocation induced by radiation but the difference was not statistically significant $(\mathrm{p}=0.077)$ (Table 3$)$.

TABLE 3 - Number and percentages of positive cultures from mesenteric lymph nodes in all groups.

\begin{tabular}{ccccc}
\hline & $\begin{array}{c}\text { Group-1 } \\
(\mathbf{n = 8})\end{array}$ & $\begin{array}{c}\text { Group-2 } \\
(\mathbf{n}=8)\end{array}$ & $\begin{array}{c}\text { Group-3 } \\
(\mathbf{n}=8)\end{array}$ & $\begin{array}{c}\text { Group-4 } \\
(\mathbf{n}=8)\end{array}$ \\
\hline $\begin{array}{c}\text { Number and } \\
\text { Percentage of } \\
\text { Positive Culture } \\
\text { Results }\end{array}$ & $1(12.5 \%)$ & $8(100 \%)^{\mathrm{a}}$ & $2(25 \%)$ & $4(50 \%)$ \\
\hline
\end{tabular}

$\mathbf{a}=\mathrm{p}: 0.001$ as statistically significant.

\section{Discussion}

The damage caused by radiation on gastrointestinal mucosal barrier is the most important dose limiting factor in abdominopelvic radiotherapy for cancer treatment ${ }^{9,16}$. This clinical tableu may appear with severe symptoms such as diarrhea, tenesmus and rectal bleeding ${ }^{17}$. A previous study reported that 18 22 Gy radiation dose range can cause acute diarrhea ${ }^{18}$. In our study diarrhea was observed after 24 hours in all the rats affected by radiation.

Gastrointestinal flora is a requirement for a healthy life. Various mechanisms prevent the bacterial overgrowth in a healthy host. These are gastric acidity, limited substrats for microorganisms, local and/or systemic immunological factors of the host and gastrointestinal motility ${ }^{19}$. Gastrointestinal flora contains up to $300-500$ species of microorganism with different characteristics $^{20}$. The variety and count of these microorganisms in intestinal flora may vary depending on drugs, diet, environmental factors and immunity of the host ${ }^{21}$. It is reported that radiation application to abdominopelvic region may change the bacterial count and variety of intestinal flora depending on its dose ${ }^{8}$. In our study, a significant increase was seen in TMAB counts and enteric bacterial counst in the cecal content of rats after acute radiation enteritis in radiation group compared to the control group.

A great number of chemical agents and oral nutrients are used for decreasing mortality and morbidity of radiotherapy induced complications $\mathrm{s}^{3,16,22}$. Although there are no study evaluating the protective effects of amifostine on bacterial overgrowth and translocation on gastrointestinal system after acute radiation enteritis. evaluation of protective effects of amifostine under different radiation types and doses in acute period were studied in recent literature.

In this experimental study, we determined that a statistically significant decrease in TMAB and enteric bacterial counts (bacterial overgrowth) after radiation in group 4 treated with amifostine compared to group $-2(\mathrm{TMAB} p=0.007$, enteric bacteria $p=0.005)$. This is the first study conducted on this subject. Therefore we could not compare our data with other studies. Recent studies reported that ionized radiation can cause acute morphological changes in intestines in 24 to 48 hours and amifostine has some protective effects against these acute effects $^{23-26}$. Our results showed that amifostine may decrease the bacterial overgrowth induced by radiation, in acute phase due to its expected protective effect on the intestinal mucosa.

In previous experimental animal models, it was showed that ionized radiation increased the bacterial translocation ${ }^{16,27}$. In our study, bacterial overgrowth was detected in all samples of lymph nodules in rats of group-2 and it was statistically significant when we compared to group-1 $(p=0.001)$.

Free oxygen radicals, generated by the induction of oxidative stress after radiation, form the fundamental toxic and inflammatory process on normal tissues ${ }^{28}$. It is expected that amifostine will decrease the bacterial translocation, however amifostine is considered to protect intestinal mucosal barrier due to its antioxidant and repairing characteristics on DNA fragmentation after radiation injury ${ }^{29}$. In our study bacterial overgrowth was determined in $100 \%$ of cultures in group- 2 affected by radiation, this percentage decreased to $50 \%$ in rats in group- 4 . Although there was no statistically significant difference between groups 2 and $4(\mathrm{p}=0.077)$.

\section{Conclusions}

Amifostine can be a useful radioprotective agent in clinical practice after acute radiation enteritis. Our study showed that amifostine significantly decreased the bacterial overgrowth in the cecal content after high dose radiation. However, it was shown that amifostine do not provide a full protection on the damaged mucosal barrier under radiation but it may decrease the bacterial translocation in gastrointestinal system.

We consider that researchers will have increased interest in radioprotective effects of amifostine. There is a need to find out appropriate amifostine dose under different radiation applications avoiding bacterial translocation in gastrointestinal system. 


\section{References}

1. Toledo-Pereyra LH. X-rays surgical revolution J Invest Surg. 2009;22(5):327-32. PMID: 19842886.

2. Grammaticos P, Giannoula E, Fountos GP. Acute radiation syndrome and chronic radiation syndrome. Hell J Nucl Med. 2013;16(1):56-9. PMID: 23570025.

3. Bounous G, Le Bel E, Shuster J, Gold P, Tahan WT, Bastin E. Dietary protection during radiation therapy. Strahlentherapie. 1975;149(5):476-83. PMID: 807995.

4. Berthrong M. Pathologic changes secondary to radiation. World J Surg. 1986;10(2):155-70. PMID: 3705602.

5. Hwang JM, Chan DC, Chang TM, Tsao TY, Tsou SS, Lu RH, Tsai LM. Effects of oral arginine and glutamine on radiation-induced injury in the rat. J Surg Res. 2003;109(2):149-54. PMID: 12643857.

6. Somosy Z, Horvath G, Telbisz A, Rez G, Palfia Z. Morphological aspects of ionizing radiation response of small intestine. Micron. 2002;33(2):167-78. PMID: 11567886.

7. Berg RD. Bacterial translocation from the gastrointestinal tract Trends Microbiol. 1995;3(4):149-54. PMID: 7613757.

8. Seal M, Naito Y, Barreto R, Lorenzetti A, Safran P, Marotta F. Experimental radiotherapy-induced enteritis: a probiotic interventional study. J Dig Dis. 2007;8(3):143-7. PMID: 17650226

9. Hauer-Jensen M, Wang J, Boerma M, Fu Q, Denham JW. Radiation damage to the gastrointestinal tract: mechanisms, diagnosis, and management. Curr Opin Support Palliat Care. 2007;1(1):23-9. PMID: 18660720.

10. Bentzen SM, Overgaard J. Patient-to-patient variability in the expression of radiation-induced normal tissue injury. Semin Radiat Oncol. 1994;4(2):68-80. PMID: 10717093.

11. Schuchter LM. Guidelines for the administration of amifostine. Semin Oncol. 1996;23(4):40-3. PMID: 8783665.

12. Yurut-Caloglu V, Caloglu M, Eskiocak S, Tastekin E, Ozen A, Kurkcu N, Oz-Puyan F, Kocak Z, Uzal C. Comparison of the protective roles of $\mathrm{L}$-carnitine and amifostine against radiation-induced acute ovarian damage by histopathological and biochemical methods. J Cancer Res Ther. 2015;11(2):447-53. PMID: 26148616.

13. Felice PA, Nelson NS, Page EE, Deshpande SS, Donneys A, Rodriguez J, Buchman SR. Amifostine reduces radiation-induced complications in a murine model of expander-based breast reconstruction. Plast Reconstr Surg. 2014;134(4):551-60. PMID: 25357049.

14. Koukourakis MI, Kyrgias G, Panteliadou M, Papadopoulou A, Tsiarkatsi M, Papachristou E, Bebeli M. Dose escalation of amifostine for radioprotection during pelvic accelerated radiotherapy. Am J Clin Oncol. 2013;36(4):338-43. PMID: 22643562.

15. Siriken B, Bayram I, Onol AG. Effect of probiotics: alone and in a mixture of Biosacc plus Zinc Bacitracin on the caecal microflora of Japanese quail. Res Vet Sci. 2003;75(1):9-14. PMID: 12801457.

16. Blair SL, Rose DM, Sachar S, Burt ME. Oral L-2oxo-4-thiazolidine reduces bacterial translocation after radiation in the Ficher rat. J Surg Res. 1996;65(2):165-8. PMID: 8903464.

17. Delia P, Sansotta G, Donato V, Messina G, Frosina P, Pergolizzi S, De Renzis C, Famularo G. Prevention of radiation-induced diarrhea with the use of VSL\#3, a new high potency probiotic preparation. Am J Gastroenterol. 2002;97(8):2150-2. PMID: 12190202.

18. Hopkins M. Radiation induced diarrhoea-literature review. Radiographer. 2004 Apr;51(1):41-5.

19. Simon GL, Gorbach SL. The human intestinal microflora. Dig Dis Sci. 1986;31(9):147-62. PMID: 3731990.

20. Nieuwenhuijs VB, Verheem A, van Duijvenbode-Beumer $\mathrm{H}$, Visser MR, Verhoef J, Gooszen HG, Akkermans LM. The role of interdigestive small bowel motility in the regulation of gut microflora, bacterial overgrowth, and bacterial translocation in rats. Ann Surg. 1998;228(2):188-93. PMID: 9712563.

21. Ersin S, Tuncyurek P, Esassollak M, Alkanat M, Buke C, Yilmaz $\mathrm{M}$, Telefoncu A, Kose T. The prophylactic and therapeutic effects of glutamine- and arginine-enriched diets on radiation-induced enteritis in rats. J Surg Res. 2000;89(2):121-5. PMID: 10729239.

22. Kanter M, Topcu Tarladacalısir Y, Akpolat M, Mercantepe T. Protective effects of curcumin and amifostine on gamma radiation-induced jejunal mucosal damage in rats. Tip Arast Derg. 2008;6(3):128-35.

23. Caloglu M, Caloglu VY, Yalta $T$, Yalcin O, Uzal C. The histopathological of L-carnitine with amifostine for protective efficacy on radiation-induced acute small intestinal toxicity. J Cancer Res Ther. 2012;8(2):260-5. PMID: 22842372.

24. Dorr RT. Radioprotectants: pharmacology and clinical applications of amifostine. Semin Radiat Oncol. 1998;8(4):10-3. PMID: 9794995

25. Mehta MP. Protection of normal tissues from the cytotoxic effects of radiation therapy: focus on amifostine. Semin Radiat Oncol. 1998;8(4):14-6. PMID: 9794996.

26. Waddell BE, Rodriguez-Bigas MA, Lee RJ, Weber TK, Petrelli NJ. Prevention of chronic radiation enteritis. J Am Coll Surg. 1999;189(6):611-24. PMID: 10589598.

27. Guzman-Stein G, Bonsack M, Liberty J, Delaney JP. Abdominal radiation causes bacterial translocation. J Surg Res. 1989 Feb;46(2):104-7. PMID: 2918713.

28. MacNaughton WK. Review article: new insights into the pathogenesis of radiation induced intestinal dysfunction. Aliment Pharmacol Ther. 2000 May;14(5):523-8. PMID: 10792113.

29. Santini V. Amifostine: chemotherapeutic and radiotherapeutic protective effects. Expert Opin Pharmacother. 2001 Mar;2(3):47989. PMID: 11336600.

\section{Correspondence:}

Ahmet Vural

Çanakkale Onsekiz Mart University

Faculty of Medicine, Department of Medical Microbiology

17100, Çanakkale, Turkey

Phone: +90 5058145628

Fax: +902862180516

ahmetvural@comu.edu.tr

Received: Nov 16, 2015

Review: Jan 14, 2016

Accepted: Feb 15, 2016

Conflict of interest: none

Financial source: none

${ }^{1}$ Research performed at DUSAM (Dicle University Health Sciences Research and Application Center) Laboratory, Diyarbakır, Turkey. 